\title{
RANCANG BANGUN DAN UJI ALAT PROSES PENINGKATAN MINYAK CENGKEH PADA KLASTER MINYAK ATSIRI KABUPATEN BATANG
}

\author{
Widayat*, Bambang Cahyono** dan Ngadiwiyono** \\ *Jurusan Teknik Kimia Fakultas Teknik Universitas Diponegoro Jl Prof Sudarto SH Tembalang Semarang \\ **Jurusan Kimia Fakultas Sain dan Matematika'Universitas Diponegoro Semarang; Email : yayat_99@yahoo.com
}

\begin{abstract}
ABSTRAK
Minyak cengkeh merupakan salah satu produk dari minyak atsiri yang dihasilkan oleh Kluster Minyak Atsiri di Kabupaten Batang. Permasalahan yang dihadapi saat ini adalah kadar eugenol yang rendah serta warna yang belum bisa memenuhi standar SII/EOA maupun SNI 062387 2006. Penelitian ini bertujuan untuk melakukan peningkatan kualitas minyak cengkeh /eugenol dengan proses adsorpsi. Hasil penelitian menujukkan bahwa: bahan minyak cengkeh belum memenuhi standar SNI 0623872006 khususnya dari warna dan kadar eugenol total. Hal ini dikarenakan dalam proses masih digunakan peralatan dari besi. Minyak cengkeh dapat ditingkatkan kadar eugenol dan perbaikan warna menjadi lebih cerah (kuning) dengan penambahan asam sitrat 0,6-10\%. Peralatan dengan pengadukan dapat digunakan dalam proses peningkatan minyak cengkeh. Daya yang terpasang sekitar 1 PK dan kapasitas setiap batch 20-30 kg dengan waktu operasi 60 menit dan temperatur $50^{\circ} \mathrm{C}$. Kemampuan UKM di Klaster Minyak Atsiri Kab Batang Jawa Tengah dapat ditingkatkan dengan kegiatan pelatihan dan Expo hasil penelitian. Pada Tahun pertama, UKM telah melakukan kegiatan analisis produk dan perbaikan minyak cengkeh sehingga memenuhi standar SNI 0623872006.
\end{abstract}

Kata Kunci: minyak cengkeh, eugenol, adsorpsi, tangki berpengaduk, persentase Fe terikat

\section{ABSTRACT}

Clove oil is a product of essential oils produced by clusters of Essential Oils in Batang. The problem faced today is that low levels of eugenol and it color doen't meet with SII / EOA and SNI 0623872006 standard. The purpose in this research for improving the quality of clove oil / eugenol with adsorption process. The results showed that: clove oil doesn't meet of SNI 0623872006 especially at colors and total eugenol. This is because the process was used equipment from iron. The eugenol and color improving to yellow bright of clove oil by adding citric acid from 0.6 to $10 \%$. Stirring equipment can be used to the process for increasing the quality of clove oil. Installing power of about 1 PK with batch of 20-30 kg capacity with 60 minutes operating time at $50^{\circ} \mathrm{C}$. The capability of UKM at clusters of Essential Oil at Batang, Central Java can be improved by training and researching Expo. In the first year, UKM had engaged in product analysis and improvement of clove oil that meets with SNI 2387062006.

Keywords: clove oil, eugenol, adsorption, stirred tank, the percentage of Fe bonded

\section{PENDAHULUAN}

Kabupaten Batang Jawa Tengah, merupakan salah satunya penghasil minyak cengkeh /eugenol di Indonesia. Di Kabupaten Batang bahkan telah berdiri suatu kluster industri tentang minyak atsiri.

Kluster ini telah ditetapkan oleh Keputusan Kepala Bappeda Kabupaten Batang Nomor : 050/164/2010 tertanggal 05 Mei 2010 Tentang Pembentukan Kelompok Kerja Klaster Forum
Pengembangan Ekonomi Kerakyatan dan Peningkatan Sumberdaya (FORPEKDA) Kabupaten Batang (Profil Kluster Minyak Atsiri Kab. Batang, 2011). Jumlah penyuling minyak sekitar 30 buah, dengan produk saat ini adalah minyak daun cengkeh, minyak batang cengkeh dan minyak nilam.

Harga minyak daun cengkeh sangat fluktuatif dengan cepat. Permasalahan yang dihadapi oleh industri /UKM adalah spesifikasi produk seperti warna minyak cengkah coklat kehitaman, kadar 
eugenol masih dibawah standar SNI. Beberapa peneliti telah pemurnian minyak cengkeh yaitu dengan Bleaching earth dimana kadar eugenol $79,66 \%$ dapat ditingkatkan menjadi 82,22\% (Silviana dkk, 2006). Penggunaan asam sitrat juga telah dilakukan untuk meningkatkan kualitas dari minyak cengkeh (Marwati dkk, 2005; Silviana, 2007) dengan $\mathrm{Na}_{2}$ EDTA /kompleksometri (Ma'mun, 2008). Semua peneliti mengungkapkan bahwa asam sitrat maupun $\mathrm{Na}_{2}$ EDTA mampu memperbaiki kualitas minyak cengkeh khususnya dari pewarnaan. Namun dari kadar eugenol masih bisa memenuhi standar SNI (BSN, 2004), namun jika yang diacu adalah standar EOA (1975) persyaratan kadar minyak eugenol belum terpenuhi. Sehingga penelitian ini akan menjawab permasalahan diatas dengan menggabungkan proses adsorpsi-distilasi.

Eugenol merupakan komponen yang sangat berguna bagi industri makanan maupun obatobatan. Kegunaan utama adalah sebagai penghambat perkembang biakan bakteri dan jamur. Dengan potensi ini eugenol dan turunan dapat membantu dalam pengawetan makanan /aditif sehingga dapat mengantikan pengawet yang sintesis. Produk ini lebih bersifat alami, sehingga aman bagi manusia. Permasalahan yang utama adalah untuk memperoleh produk yang memenuhi standar EOA /SII atau SNI sampai saat ini masih kesulitan, sehingga penelitian yang bersifat aplikatif dapat diterapkan dalam mengatasi masalah tersebut. Proses adsorpsi dapat mengatasi permasalahan warna yang dihasilkan dari proses penyulingan minyak cengkeh yang konvensional (Silviana dkk (2006), Silviana (2007), Ma'mun (2008) dan Marwati dkk (2005)). Dengan hasil penelitian tersebut, dapat dikembangkan proses adsorpsi skala pilot plant dan diaplikasikan untuk mengatasi warna dari minyak cengkeh. Adapun untuk mengatasi kadar atau konsentrasi eugenol dapat dikembangkan proses distilasi dengan operasi vakum. Dengan kegiatan ini, teknologi tepat guna dapat diciptakan bahkan dapat mengatasi permsalahan yang ada bagi industri makanan-minuman (industri minyak astiri).

Minyak cengkeh merupakan minyak atsiri yang diperoleh dari tanaman cengkeh (Eugenia caryophyllata Thunb). Minyak atsiri ini dapat diperoleh dari bunga, batang, dan daun tanaman cengkeh. Kualitas minyaknya dievaluasi dari kandungan fenol, terutama eugenol. Kandungan eugenol dalam minyak bunga, gagang /batang dan daun cengkeh sangat dipengaruhi oleh keadaan bahan baku, metode penyulingan minyak dan (C) 2012, Program Studi Ilmu Lingkungan Program Pasca Sarjana UNDIP pengambilan eugenol dari minyak. Kadar eugenol dalam minyak cengkeh dipengaruhi oleh asal minyaknya. Kadar terbanyak dan kualitas yang baik dapat dihasilkan oleh minyak yang diperoleh dari bunga dan gagang cengkeh. Kualitas minyak daun cengkeh hanya sedikit lebih rendah dibandingkan dengan minyak bunga atau gagang cengkeh.

Minyak daun cengkeh dapat dihasilkan dengan cara penyulingan dari daun tanaman cengkeh yang telah luruh. Umumnya penyulingan minyak daun cengkeh di Indonesia merupakan industri tradisional yang dikelola petani cengkeh. Para petani lebih suka menjual bunga cengkeh langsung ke pedagang daripada melakukan penyulingan bunga cengkeh. Kabupaten Batang Propinsi Jawa Tengah merupakan salah satu Kluster Minyak Atsiri, dimana produk usaha meliputi; minyak cengkeh dan minyak nilam. Adapun keanggotaan Kluster ini tersebar di 7 Kecamatan Wilayah Bagian Selatan/Dataran Tinggi yaitu : Kec. Wonotunggal, Bandar, Blado, Reban, Pecalungan, Bawang dan Tersono.

Eugenol adalah sebuah ikatan allyl $\left(\mathrm{C}_{10} \mathrm{H}_{12} \mathrm{O}_{2}\right)$ atau nama lainnya adalah 2-methoxy-4-(2propenyl) phenol dan merupakan anggota dari Allyl benzene. Eugenol reaktif terhadap basa kuat khususnya $\mathrm{NaOH}$ dan $\mathrm{KOH}$. Eugenol berupa zat cair berbentuk minyak tidak berwarna atau sedikit kekuning-kuningan. Eugenol dapat larut dalam alkohol, kloroform, eter dan sedikit larut dalam air, berbau tajam minyak cengkeh, berasa membakar dan panas di kulit. Eugenol memiliki titik didih $256^{\circ} \mathrm{C}$, titik leleh $-9{ }^{\circ} \mathrm{C}$, titik nyala $104{ }^{\circ} \mathrm{C}$, tekanan uap $10 \mathrm{mmHg}$ pada $123^{\circ} \mathrm{C}$, densitas $1,064-1,068$ $\mathrm{g} / \mathrm{mL}$, berat molekul $164,20 \mathrm{gr} / \mathrm{mol}$ dan indeks bias 1,541 pada $20^{\circ} \mathrm{C}$. Struktur kimia Eugenol seperti disajikan dalam Gambar 1.<smiles>C=CCc1ccc(O)c(OC)c1</smiles>

\section{Gambar 1. Struktur kimia Eugenol}

Penelitian ini bertujuan untuk meningkatkan kualitas produk minyak cengkeh dengan proses adsoprsi dan merancang peralatan untuk proses tersebut. 


\section{Metode Penelitian}

Kegiatan penelitian merupakan kegiatan terapan, sehingga peralatan yang dirancang merupakan skala pilot plant. Adapun kapasitas operasi /produksi ditentukan setelah dilakukan kajian di lapangan lebih detail dengan memperhitungkan kapasitas produksi dari UKM saat ini. Dengan demikian tidak proses produksi dapat berjalan sinambung. Data-data yang digunakan untuk perancangan terlebih dahulu diperoleh dalam penelitian skala laboratorium.

Data-data mentah diperoleh dengan melakukan survey secara menyeluruh potensi UKM yang tergabung di kluster Minyak Atsiri Kab. Batang Propinsi Jawa Tengah. Data-data ini meliputi data teknis tentang UKM, kapasitas produksi sampai dengan tenaga kerja dan kemampuan penyediaan energi. Untuk memperoleh sinergisitas dan kemanfaatan yang nyata bagi UKM atau industri, pada akhir kegiatan dilakukan diseminasi, dimana bentuk kegiatan adalah EXPO dan pelatihan serta workshop. Kegiatan dilakukan dengan melakukan kerjasama dengan PEMDA (BAPPEDA Kabupaten Batang dan Jawa Tengah).

\section{Bahan dan Alat}

Bahan yang digunakan dalam penelitian ini adalah minyak daun cengkeh yang diperoleh dari Klaster minyak atsiri Kab. Batang. Bahan baku dilakukan analisis dengan metode SNI yang meliputi warna dan bau, indek bias, densitas, viskositas, kelarutan dalam etanol dan eugenol total. Asam sitrat engan kualitas industri digunakan untuk proses perbaikan minyak cengkeh.

\section{Hasil Dan Pembahasan}

\section{Analisis Bahan Baku minyak Cengkeh}

Minyak cengkeh dapat diperoleh dari tanaman cengkeh dari bagian daun, batang /gagang dan bunga (Guenther, 1987). Minyak cengkeh yang dihasilkan dari kluster minyak atsiri diperoleh dari batang dan daun. Adapun dalam penelitian sebagai bahan baku diperoleh dari Kluster Minyak Atsiri Kabupaten Batang. UKM tempat pembelian bahan adalah eugenol yaitu UKM milik Bapak Harjito Senoaji. Bahan eugenol selanjutnya dianalisis menurut standart SNI minyak cengkeh (terlampir). Hasil analisis dibandingkan dengan standar SNI seperti disajikan dalam Tabel 1; Hasil analisis menunjukkan bahwa minyak cengkeh belum memenuhi standar dari sisi kadar eugenol dan warna. Dengan kondisi seperti, selanjutnya dilakukan penelitian dan perancangan alat untuk memenuhi standar SNI minyak cengkeh khususnya untuk warna dan kosentrasi eugenol dala minyak cengkeh.

Tabel 1. Hasil analisis bahan baku

\begin{tabular}{|c|c|c|}
\hline Parameter & Hasil analisis & $\begin{array}{c}\text { Standar } \\
\text { SNI 06-2387-2006 }\end{array}$ \\
\hline Keadaan: warna dan & Hitam & Kuning-coklat tua \\
\hline bau & Bau khas cengkih & Bau khas cengkih \\
\hline $\begin{array}{l}\text { Bobot jenis } \\
\text { (densitas) } 20^{\circ} / 20^{\circ} \mathrm{C}\end{array}$ & 1,030 & $1,025-1,049$ \\
\hline Indeks bias $\left(\mathrm{nD}_{20}\right)$ & 1,530 & $1,528-1,535$ \\
\hline $\begin{array}{l}\text { Kelarutan dalam } \\
\text { etanol }\end{array}$ & 1:2 jernih & 1:2 jernih \\
\hline Kadar eugenol total & $70 \%$ & Min $78 \%$ \\
\hline Kadar caryophilene & $20 \%$ & Maksimum $17 \%$ \\
\hline
\end{tabular}

Gambar 2. Kromatogram GCMS Minyak Daun Cengkeh

Tabel 2. Komponen dalam Crude Minyak Daun Cengkeh

\begin{tabular}{lll}
\hline R-Time & Komponen & $\%$ Komposisi \\
\hline 11,243 & Alpha cubebene & $0,17 \%$ \\
11,548 & Eugenol & $73,12 \%$ \\
11,775 & Alpha Copaene & $0,55 \%$ \\
12,565 & Trans-caryophyllene & $22,41 \%$ \\
13,080 & Alpha humulene & $2,64 \%$ \\
\hline
\end{tabular}

Selain analisis menurut standar SNI minyak cengkeh, bahan baku juga dianalisis dengan kromatografi gas dan spektrofotometri massa (GCMS). Kegiatan analisis dilakukan di Laboratorium kimia analisis Fakultas MIPA UGM, dimana hasil analisis disajikan dalam gambar 2 . Hasil analisis menampilkan 5 buah kromatogram dengan waktu retensi dari 11,243 menit sampai 13 menit. Hasil analisis secara lengkap disajikan dalam tabel 2. konsetrasi eugenol dalam minyak cengkeh. Hasil analisis ini mendukung analisis sebelumnya (SNI) dimana konsentrasi eugenol hanya $73 \%$. Komponen impuritas dalam minyak cengkeh didominasi oleh trans-caryophyllene dan alpha humilene. Minyak daun cengkeh mengandung dua komponen utama yaitu eugenol 
(70 \% - $80 \%$ ) dan kariofilen (15\% - $20 \%$ ) serta beberapa komponen dalam jumlah kecil. Komponen yang sudah diketahui adalah $\beta$ kariofilena, $\alpha$-kubeben, $\alpha$-kopaen, humulen, $\gamma$ kadien, dan kadina 1,3,5-trien. Hasil pengamatan Kadar Fe awal dalam minyak daun cengkeh dengan menggunakan analisa AAS adalah 176,9 ppm.

\section{Perbaikan Minyak Cengkeh \\ Studi Penelitian Pendahuluan}

Hasil analisis menunjukkan bahwa warna dan konsentrasi eugenol yang belum memenuhi standar SNI. Beberapa penelitian tengang peningkatan minyak cengkeh yang telah dilakukan diantaranya Silviana dkk, (2006) dimana proses peningkatan dengan bleaching earth. Hasil yang diperoleh menunjukkan bahwa tanah pemucat dapat digunakan dalam peningkatan minyak cengkeh. Penelitian yang lain juga telah dilakukan oleh Marwati dkk, (2005), Silviana (2007) dan Ma'mun (2008) dimana asam sitrat digunakan sebagai bahan pengkelat dan kompleksometri. Hasil penelitian menunjukkan bahwa metode ini berpotensi untuk memperbaiki minyak cengkeh. Untuk tahap ini dipilih suatu metode yang aman terhadap minyak cengkeh. Sehingga dipilih proses perbaikan minyak cengkeh dengan penambahan asam sitrat. Sebelum dipilih metode mana yang dipakai, dilakukan ujicoba dengan dua proses yaitu dengan penambahan asam sitrat dan zeolit alam. Zeolit alam dilakukan perlakuan kimia dan fisika yaitu dengan penambahan asam klorida dan kalsinasi. Percobaan yang lain dilakukan penambahan asam sitrat $0,6 \%$ tanpa pemanasan. Percobaan dilakukan dengan pertimbangan efisiensi biaya khususnya untuk pemanasan. Selain itu juga dilakukan permunian dengan menggunakan zeolit alam yang teraktifasi. Hasil eksperimen didokumentasi dan disajikan dalam gambar 3.

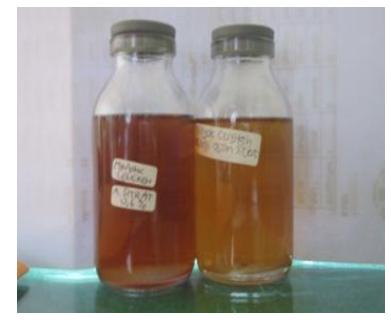

a. Asam sitrat $0,6 \%$ dan $10 \%$

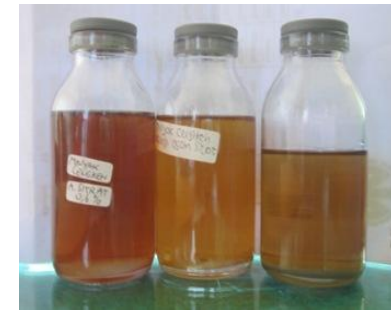

b. asam sitrat -zeolit
Gambar 3. Produk hasl proses pemurnian minyak cengkeh

Hasil penelitian menunjukkan bahwa penambahan asam sitrat pada konsentrasi asam sitrat 0,6 dan $10 \%$ mempunyai kemampuan untuk memperbaiki kualitas minyak cengkeh dari sisi warna minyak. Gambar 3. a menunjukkan bahwa penambahan asam sitrat konsentrasi 10\% lebih cerah warnannya dibandingkan dengan penambahan asam sitrat konsentrasi 0,6\%. Hal ini dikarenakan bahwa besi yang terikat dalam eugenol dapat diikat oleh asam sitrat lebih banyak. Namun sisi asam sitrat tentunya tidakdiinginkan dalam minyak cengkeh. Penambahan asam sitrat $0,6 \%$ juga telah memenuhi standar Sni. Untuk memperoleh kondisi yang terbaik dilakukan optimasi proses perbaikan minyak cengkeh.

Gambar 3.b menunjukkan bahwa zeolit alam juga mempunyai kemampuan untuk memperbaiki minyak cengkeh dimana digunakan zeolit alam sekitar $2 \%$. Penggenunaan zeolit alam mempunyai efek dalam bau, dimana bau mengalami perubahan dari bau khas cengkeh menjadi bau wangi vanili. Dengan demikian diduga dalam ada reaksi kimia pembentukan vanili. Sehingga proses yang dipilih untuk perbaikan minyak cengkeh adalah penambahan dengan asam sitrat.

\section{Rancang Bangun Alat Perbaikan Minyak Cengkeh}

Proses perbaikan minyak cengkeh difokuskan dengan pengolahan dengan penambahan asam sitrat. Peralatan yang dipilih tentunya merupakan tangki berpengeaduk dna dilengkapi dengan pemanas. Dengan demikian, kegiatan pada tahap ini meliputi tahap rancang bangun dan fabrikasi serta ujicoba.
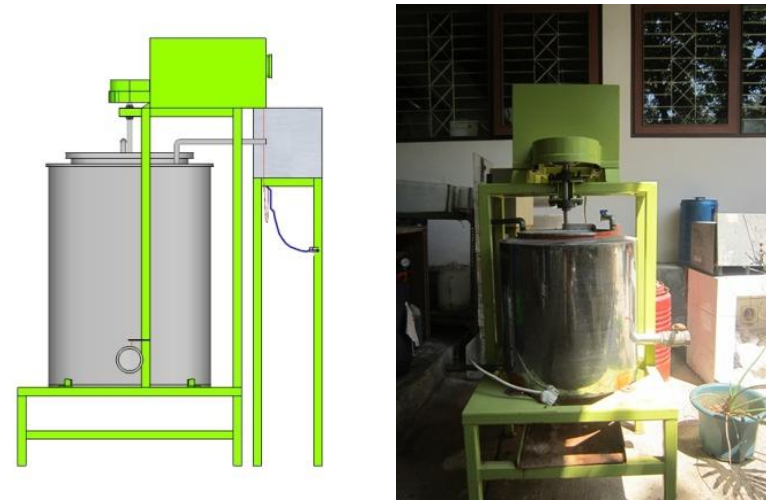

Gambar4. Alat tangki adsorpsi kimia

Proses perbaikan minyak cengkeh dilakukan dengan proses curah, dimana kapasitas setiap prosesnya skitar 20-30 kg. Peralatan yang dibuat pada Gambar 4. terdiri dari tangki yang dilengkapi dengan isolasi, pengaduk dan pemanas. Pengadukan terdiri dari impellar dengan sistem 
sirip dengan jumlah 4 buah, yang terletak pada bagian dasar dengan jarak dari bawah sekitar $5 \mathrm{~cm}$. Pengaduk digerakan oleh motor dengan kapasitas sekitar 1,5 PK, dimana sistem pergerakan dengan pully sehingga tangkai pengaduk dengan motor tidak terhubung secara langsung. Sistem pemanasan dengan menggunakan kompor gas, yang dilengkapi dengan pengukur temperatur sehingga kondisi operasi dapat dijaga. Produk setelah operasi dikeluarkan dari bawah, dengan cara membuka kran yang ada bagian bawah. Operasi dilangsungkan selama 30-60 menit pada temperatur $40-50^{\circ} \mathrm{C}$.

Berdasarkan hasil survey yang kedua ke Klaster Minyak Atsiri dimana kemampuan energi listrik yang dimiliki oleh setiap UKM berbeda-beda. Dengan kondisi seperti ini dilakukan perubahan terhadap daya yang digunakan untuk proses pengadukan yaitu 1PK. Rancangan yang diterapkan di UKM atau Klaster seperti. Peralatan difabrikasi di SMK yang ada di Kabupaten Batang. Hal ini bertujuan sebagai sarana pembelajran bagi siswa siswa SMK juga, sehingga dapat membantu dalam praktek pembuatan peralatan bagi industri.

Hasl ujicoba menunjukkan bahwa peralatan dapat meningkatkan kandungan eugenol total sekitar 3-5\%. Selain itu warna eugenol yang diperoleh juga menjadi lebih baik dan memenuhi standar SNI SNI 062387 2006. Dengan demikian peralatan ini dapat mengatasi permasalahan tentang produk yang tidak memenuhi standar SNI SNI 0623872006.

\section{KESIMPULAN}

Berdasarkan penelitian yang telah dilakukan dapat diambil kesimpulan sebagai berikut;

1. Bahan minyak cengkeh belum memenuhi standar SNI 0623872006 khususnya dari warna dan kadar eugenol total. Hal ini dikarenakan dalam proses masih digunakan peralatan dari besi.

2. Minyak cengkeh dapat ditingkatkan kadar eugenol dan perbaikan warna menjadi lebih cerah (kuning) dengan penambahan asam sitrat 0,6-10\%. Peralatan dengan pengadukan dapat digunakan dalam proses peningkatan minyak cengkeh. Daya yang terpasang sekitar 1 PK dan kapasitas setiap batch 20-30 kg dengan waktu operasi 60 menit dan temperatur $50^{\circ} \mathrm{C}$.

3. Kemampuan UKM di Klaster Minyak Atsiri Kab Batang Jawa Tengah dapat ditingkatkan dengan kegiatan pelatihan dan Expo hasil penelitian. Pada Tahun pertama, UKM telah melakukan kegiatan analisis produk dan perbaikan minyak cengkeh sehingga memenuhi standar SNI 06 23872006.

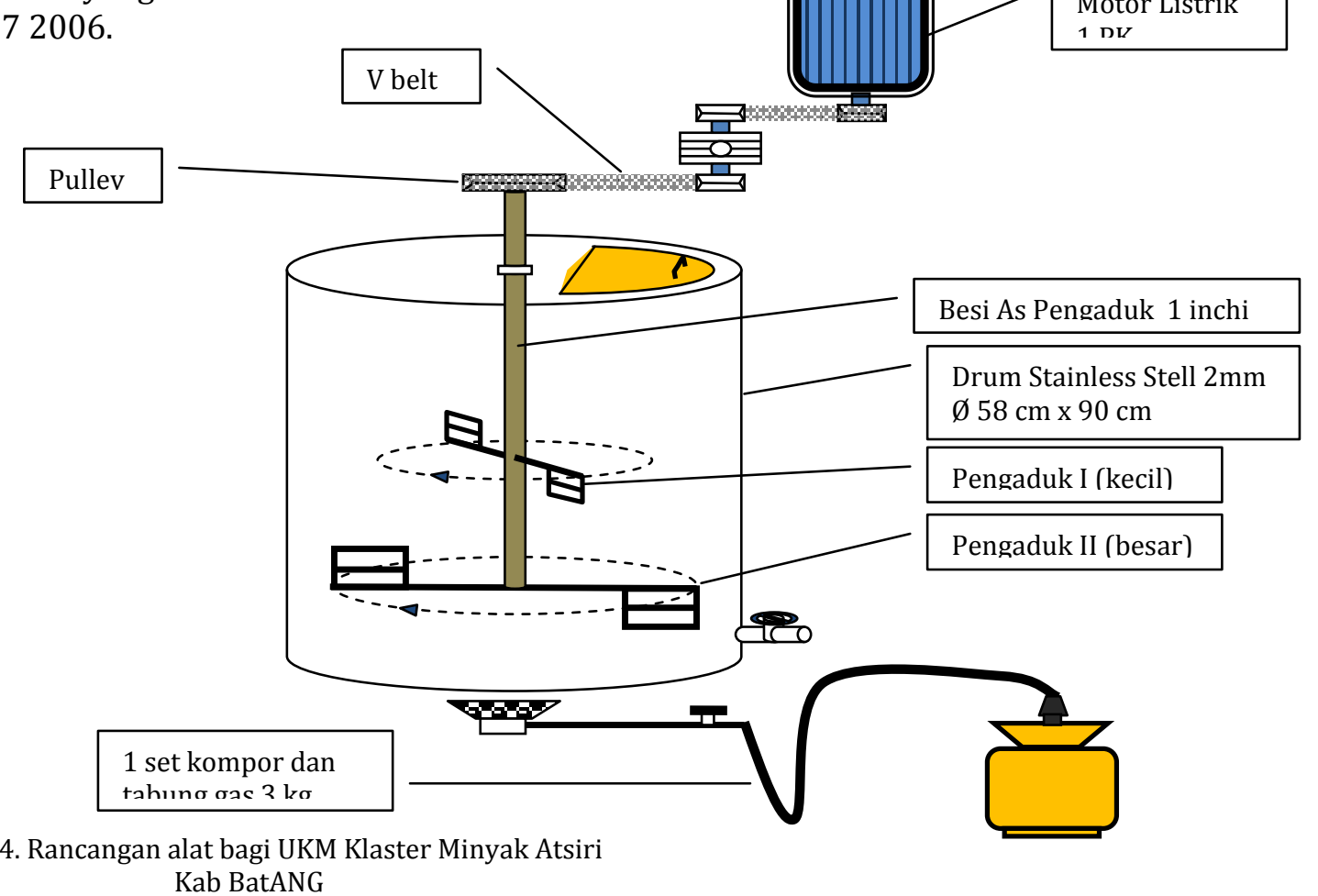

Gambar 4. Rancangan alat bagi UKM Klaster Minyak Atsiri Kab BatANG 


\section{DAFTAR PUSTAKA}

BADAN STANDARISASI NASIONAL, 2006, Standar Nasional Indonesia Minyak Cengkeh.

BIRO PUSAT STATISTIK, 2004. Ekspor Minyak Atsiri Indonesia

EOA (ESSENTIAL OIL ASSOCIATION) OF USA. 1975. EOA Spesifications and Standards. New York. p.35-37.

Guenther, E., (1987), Minyak Atsir", Jilid I, penerjemah: S. Ketaren, hal. 19-20, 99-274. Penerbit Universitas Indonesia. Jakarta.

Klaster Minyak Atsiri Kab. Batang, 2011, Profil Klaster Minyak Atsiri Kab. Batang

MASADA, Y. 1985. Analysis of Essential Oils by Gas Chromatography and Mass Spectrometry. John Willey \& Sons. Inc. London. 270p

Ma'mun (2008) Pemurnian Minyak Nilam Dan Minyak Daun Cengkeh Secara Kompleksometri, Jurnal LITTRI, Vo. 4 No. 1 Hal 36-42

Marwati T, Meika Syahbanna Rusli, Erliza Noor dan Edy Mulyono, (2005), Peningkatan Mutu Minyak Daun Cengkeh Melalui Proses Pemurnian, Jurnal Pasca Panen (2) Hal 45-52
Profil Kluster Minyak Atsiri Kabupaten Batang Propinsi Jawa Tengah, 2011

Shelly Todd E., James and Donald McInnis, (2010) Pre-Release consumption of methyl eugenol increases the mating competitiveness of sterile males of the oriental fruit fly, Bactrocera dorsalis, in large field enclosures, Journal of Insect Science: Vol. 10

Silviana, Revi O.A., dan Errysa P, (2006), Peningkatan Mutu Minyak Daun Cengkeh Rakyat melalui Proses Adsorbsi dengan Bleaching Earth, Prosiding Seminar UPN "Kejuangan". Yogyakarta.

Silviana, (2007), Proses Pengkelatan Minyak Cengkeh dengan Asam Sitrat, Jurnal Metana, Program Diploma Fakultas Teknik Universitas Diponegoro Semarang

Vidhya N dan S N. Devaraj (2011), Induction of apoptosis by eugenol in human breast cancer cells, Indian Journal of Experimental Biology, Vol.49 hal 871-878 